\title{
The Globalization of Stock Markets and Convergence in Corporate Governance
}

\author{
Gerald F. Davis and Christopher Marquis
}

THE INTERNATIONAL INTEgRATION of financial markets is a central dynamic of the globalization process and a potent force for driving changes in the institutions of corporate governance. During the late 1980s and 1990s, cross-border portfolio investment expanded dramatically. The number of regional and global investment funds focused on emerging markets increased from nine in 1986 to nearly 800 in 1995, and the combined assets of emerging market funds grew from $\$ 1.9$ billion $\$ 132$ billion during this time (World Bank 1997: 16). Conversely, the number of foreign companies listed on the two major U.S. stock markets (Nasdaq and the New York Stock Exchange) increased from roughly 170 in 1990 to over 750 in 2000. ${ }^{1}$ There are now more non-U.S. companies traded on Nasdaq and NYSE than there are German corporations traded on the Deutsche Borse. Some theorists have taken these trends to indicate a coming convergence in the institutions of corporate governance around the world, at either the national or the firm level (see Davis and Useem 2001 for a review). At the national level, states may adapt their system of corporate governance to the American model in order to achieve the growth benefits of "shareholder capitalism" (e.g., Levine and Zervos 1998). As Larry Summers put it, "Financial markets don't just oil the wheels of economic growth-they are the wheels" (Murray 1997). Thus, forty-three nations opened their first postwar local stock exchange during the 1980s and 1990s, often as a means to attract foreign portfolio investment in local companies (Weber and Davis 2000). At the firm level, managers of companies seeking to attract equity investors have strong incentives to follow the standards of American institutional investors for appropriate governance structures. The ultimate impact, according to enthusiasts, will be the worldwide dominance of the American model of how to finance and govern a corporation.

Discussions of the "American model" portray it as a blueprint for an institutional matrix oriented toward dispersed investors, from the proper way to compose a board of directors to how to generate shareholderfriendly bodies of corporate and securities law (Easterbrook and Fischel 
1991; cf. North 1990). But to the extent that the "American model" is a coherent construct at the national level, there are substantial legal and cultural barriers to its spread across nations (Guillen 2001), and many of the relevant institutions of corporate governance-such as stock markets-are not strictly contained within nation-states. It is largely the choices of decision-makers within firms that determine how corporations will be structured, from what stock market they list on and how they compose the board of directors to the strategy and goals of the firm. Law and culture provide some constraints at the firm level, of course, but these constraints are arguably more negotiable now than at any time in history.

We argue in this chapter that the appropriate level of analysis to address the issue of convergence in corporate governance is the individual firm, and that organization theory provides a useful toolkit for linking the macro aspects of economic globalization to the micro processes of business decision making. In their introduction, the editors of this volume argue that "economic sociologists need to ... specify the mechanisms that account for continuity and discontinuity in institutional structures." Organization theory provides an extensive suite of theoretical mechanisms to understand processes of corporate change, including selection, diffusion, and the birth of new entrants to organizational fields. By examining how national context conditions the choices available to corporate decision-makers, and specifying the organizational processes underlying field-level change in the institutions of corporate governance, we hope to contribute to the project of explaining institutional continuity and discontinuity at the macro level.

Moreover, while institutions constrain firms, decision-makers within firms can choose their institutional jurisdiction. U.S. corporations have long experience with this notion: while securities law is national in scope, corporate law is made by states, and companies choose their state of incorporation, thereby creating competition among state legislatures to provide corporate law that appeals to corporate decision-makers (Romano 1993). To an increasing extent such institutional competition now takes place at a global level, as choices about where a firm incorporates (corporate law) and what market its securities trade on (securities law) are decoupled from where a firm is headquartered and where production takes place. By some accounts, just as Delaware won the competition to be the preferred state of incorporation, U.S. stock markets are likely to emerge as the preferred trading locale through voluntary "institutional migration" by global firms.

In this chapter, we examine the consequences of listing on a U.S. stock market for the governance practices of non-U.S. firms. Our general questions are: Do U.S.-listed foreign firms adopt the governance practices 
typical of American firms, and what effect does this have on their patterns of ownership and control? We study the network ties, governance structures, disclosure patterns, and investor recognition of 209 firms listed on Nasdaq and the New York Stock Exchange from the UK, France, Germany, Japan, Chile, and Israel in 2000. Each of these nations represents a divergent tradition of corporate governance and thus a different starting place for convergence. To the extent that stock markets are a device for homogenizing the practice of corporate governance around the world, it should be most visible among these firms.

Listing on a U.S. stock market is a compelling way for foreign firms to signal their shareholder orientation because it requires them to meet the relatively stringent standards of American securities markets (see Licht 1998 for a review of the empirical evidence on foreign listings). Indeed, Coffee (1999) argues that the dominant multinationals of the future- those whose higher valuations allow them to survive global industry consolidationwill tend to be listed on U.S. stock markets, and thereby subject to American securities laws, accounting standards, and the listing criteria of their chosen market. This is not trivial: when Daimler-Benz (Germany's largest industrial corporation) chose to list on the New York Stock Exchange in 1993, its 1992 earnings of DM 615 million under German accounting standards had to be restated as a loss of DM 1,839 million under U.S. standards. Moreover, disclosure requirements under U.S. securities law extend to transparency of corporate ownership. In principle, a Russian citizen or group that accumulates 5 percent of the shares of an Italian firm that lists ADRs on the NYSE is required to disclose its stake and intentions to the Securities and Exchange Commission, which makes such information publicly available (Coffee 1999). More recently, the SEC announced that foreign private issuers would be required to disclose activities in countries facing U.S. government sanctions, such as Cuba (Economist 2001).

But listing on a U.S. market falls short of adopting "shareholder capitalism" tout ensemble. Shareholder capitalism is more a genre of corporate capitalism than a prescription for specific governance practices. As such, its spread is akin to acculturation, for which listing on a U.S. market is only a first step. Organization theory suggests several possible pathways to convergence that may imply divergent patterns in the spread of governance practices among U.S.-listed firms, from institutional inertia-in which foreign firms retain the structures they had at their founding (Stinchcombe 1965) - to complete isomorphism (DiMaggio and Powell 1983). Examining the discretionary governance practices of U.S.-listed corporations from the perspective of organization theory gives some sense of the prospects for convergence going forward. 


\section{The Globalization of Stock Markets AND Governance CONVERgence}

The international expansion of financial markets in the late 1980s and 1990s generated a vigorous interdisciplinary analysis of the institutions of corporate governance around the world. The study of corporate governance expanded from evaluations of specific governance mechanisms in large U.S. corporations (e.g., boards of directors, capital structures, and takeovers) to cross-country comparisons of national systems for channeling capital and their impact on economic growth. The very definition of the object of study expanded correspondingly, from "the ways in which suppliers of finance to corporations assure themselves of getting a return on their investment" (Shleifer and Vishny 1997:737) to "the whole set of legal, cultural, and institutional arrangements that determine what publicly traded corporations can do, who controls them, how that control is exercised, and how the risks and returns from the activities they undertake are allocated" (Blair 1995:3). By hypothesis, some institutional configurations are better than others for generating economic growth (cf. North 1990), and institutional analysis can guide public policy by locating the best-performing model of economic organization and transplanting relevant elements (e.g., to transitional economies).

Some enthusiasts concluded that the American model, in which corporations are financed primarily by financial markets and governance institutions compel managerial attention to share price, was destined to emerge as the global standard in a world of internationally mobile capital (see, e.g., Friedman's [1999] distillation of the current received view). At the national level, the vibrancy of financial markets is empirically associated with subsequent economic growth (e.g., Levine and Zervos 1998), giving policy makers an incentive to create an institutional infrastructure conducive to vibrant financial markets. At the firm level, the ability to raise capital at low cost is a competitive advantage, and those firms that have structured themselves to be attractive to arms-length investors are the ones most likely to survive and grow. Because a disproportionate amount of investment capital is controlled by American institutional investors and others sharing their models of appropriate corporate governance, managers of firms - especially those with global aspirations-have incentives to structure themselves according to their templates (see a review and critique in Davis and Useem 2001). In effect, this means adopting the practices typical of U.S. firms: much as Toyotaism became the world's standard for manufacturing, American-style shareholder capitalism is en route to becoming the world's standard for corporate governance (Useem 1998). Thus, Bradley et al. (1999) argue that "The Anglo-American governance 
system . . notwithstanding its idiosyncratic historical origins and its limitations, it is clearly emerging as the world's standard."

While this exuberance around the financial market-based model may be premature, one salutary outcome has been a resurgence of interdisciplinary research on the links among law, finance, social structure, and economic growth in the late 1990s. By the end of the decade, claiming that "institutions matter" had gone from apostasy to received wisdom, even within financial economics. Yet there is little agreement even within the relatively circumscribed realm of law and economics as to how institutions matter. Some see nations as rigidly constrained by events and choices made long ago, and the prospects for the spread of the American model as quite limited. Mark Roe (1994) argued that nineteenth-century populism was ultimately responsible for the American system of corporate governance, in which banks are weak, financial markets expansive, and corporate ownership dispersed. In contrast, nations that inherit French civil law rather than English common law typically have poorly developed financial markets and concentrated corporate ownership because of their relatively weak protection of minority investors (LaPorta et al. 1999). Factors ranging from the power of those with inherited wealth (Morck et al. 1999; Rajan and Zingales 2000) to the proportion of Roman Catholics in the population (LaPorta et al. 1999) all limited the likelihood of institutional change in the direction of shareholder capitalism at the national level. The U.S. was like the institutional equivalent of the Galapagos Islands, having evolved an intricately interdependent ecosystem in which managerialist corporations with dispersed ownership could thrive and contribute to national economic growth. Removed from this ecosystem, however, their prospects were dim; in particular, under code law (shared by most former French colonies or protectorates), managerialist firms find few investors.

The alternative view argues that corporate decision-makers face an array of choices among suppliers of legal and regulatory institutions that do not necessarily limit them to domestic providers. In this "issuer choice" view, law is a product and decision-makers in public corporations are consumers that shop among different vendors to find the best product to maximize shareholder wealth. Their concern with shareholder wealth is not driven by altruism but by the fact that the company's securities are products that must be sold in a competitive marketplace. Managers of firms competing for investment voluntarily adopt internal structures and practices that limit their own discretion and align their interests with those of investors because these structures make the company's securities more highly valued (Easterbrook and Fischel 1991). By the same token, managers in the U.S. choose their state of incorporation in part to certify that they are being governed by rules that are best for shareholders. Firms can easily re-incorporate 
if an alternative legal regime proves superior for investors, and thus state legislatures compete to provide investor-friendly regimes of corporate law in order to capture corporate franchise revenues (Romano 1993). Stock markets also compete to provide listing standards and regulations valued by corporate managers and investors, and firms can change their listing market to appeal to investors (Rao et al. 2000). And more recently, nation-states in effect compete to provide securities regulation valued by stock markets, corporations, and investors (Licht 2000). There are several devices available for corporations to circumvent domestic institutions and choose a new institutional jurisdiction for corporate governance (e.g., creating a separate corporation in the preferred locale which then merges with the old entity; see Gilson 2001).

It is possible, of course, that both accounts are correct: national institutions may be relatively inert, and issuers may choose to migrate to new institutional jurisdictions, so that a lack of convergence at the national level does not eliminate the prospect for convergence at the firm level. What seems clear is that this institutional migration is far more prevalent now than it was even ten years ago. Just as multinational corporations may choose among low-cost locales for production around the world, they are increasingly able to make delicately calibrated choices of their place of incorporation and stock market listing. For example, several Chinese firms are headquartered in Hong Kong, incorporated in the British Virgin Islands, and trade in the U.S. on Nasdaq. In matters of corporate governance, institutions constrain firms, but managers of firms elect which institutions they choose to be constrained by. Thus, to understand globalization in corporate governance, one must unpack the organizational processes involved in issuer choice.

In this context, the recent upsurge of foreign firms listing shares on U.S. markets merits attention. By 1998, upward of 1000 companies were traded on U.S. markets (Geiger 1998), and the number traded on the New York Stock exchange had tripled over a five-year period. As figure 1 shows, several foreign firms have been listed for decades: a few British firms listed in the late 1950s and 1960s, and a handful of large Japanese firms listed during the 1970s. But the 1990s witnessed the range of nationalities with substantial U.S. listings expand to include Chile, France, Germany, Hong Kong, Israel, and Mexico (see figure 2).

Why are these firms listing in the U.S.? The empirical literature indicates that when U.S. firms list securities abroad, they suffer share price declines, while foreign companies listing in the U.S. experience increases (see Licht 1998 for a review). This might reflect several factors: firms listing in the U.S. might be those in industries in which U.S. markets provide a higher valuation, and the U.S. capital markets are far larger and more liquid than those in other countries (Velli 1994). But a more intriguing interpretation 


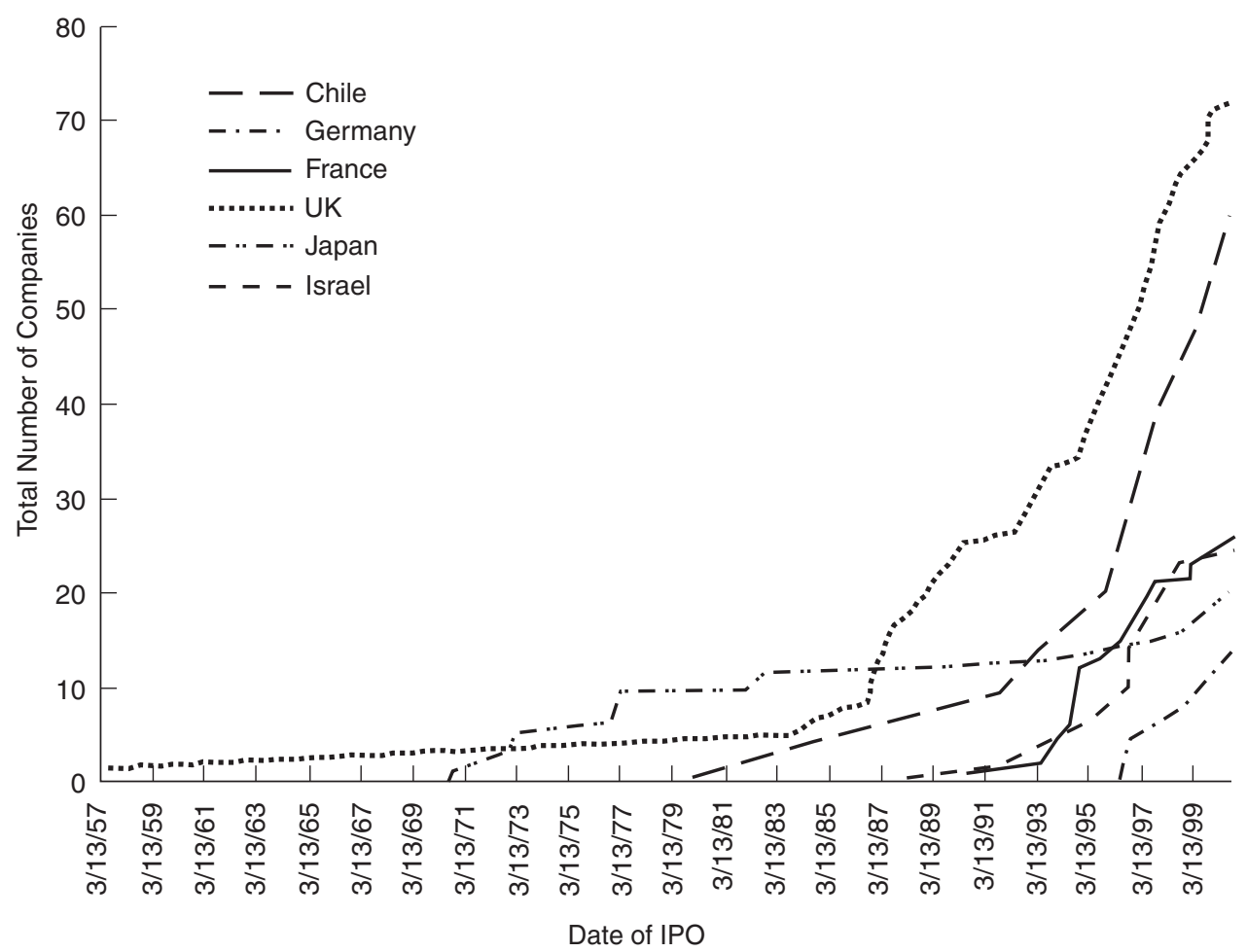

Figure 1 Growth in U.S. listings among six countries.

of these findings is that U.S. markets provide a more rigorous regulatory regime that favors investors: "the United States boasts a strict set of mandatory disclosure rules and a vast industry of securities houses and securities analysts. Taken together, the American market operates as a powerful monitoring and pricing system" (Licht 1998: 582). Thus, a U.S. listing may be seen as a bonding mechanism and a signal of the firm's proposed adherence to shareholder-oriented corporate governance. Moreover, American markets actively court foreign issuers, with substantial success (see figures 1 and 2). More than 60 firms from Israel trade on U.S. markets, for example, and several are incorporated in the U.S. and funded by American venture capitalists (Rock 2001).

Most firms that list on U.S. markets do so by sponsoring American Depository Receipts (ADRs). ADRs are certificates representing foreign shares held by a custodian bank in the issuer's home country that trade like other U.S. securities and are denominated in dollars. ADRs were invented in the 1920s as a way for U.S. investors to buy foreign securities without the transaction costs and risks of buying them on local markets in local 


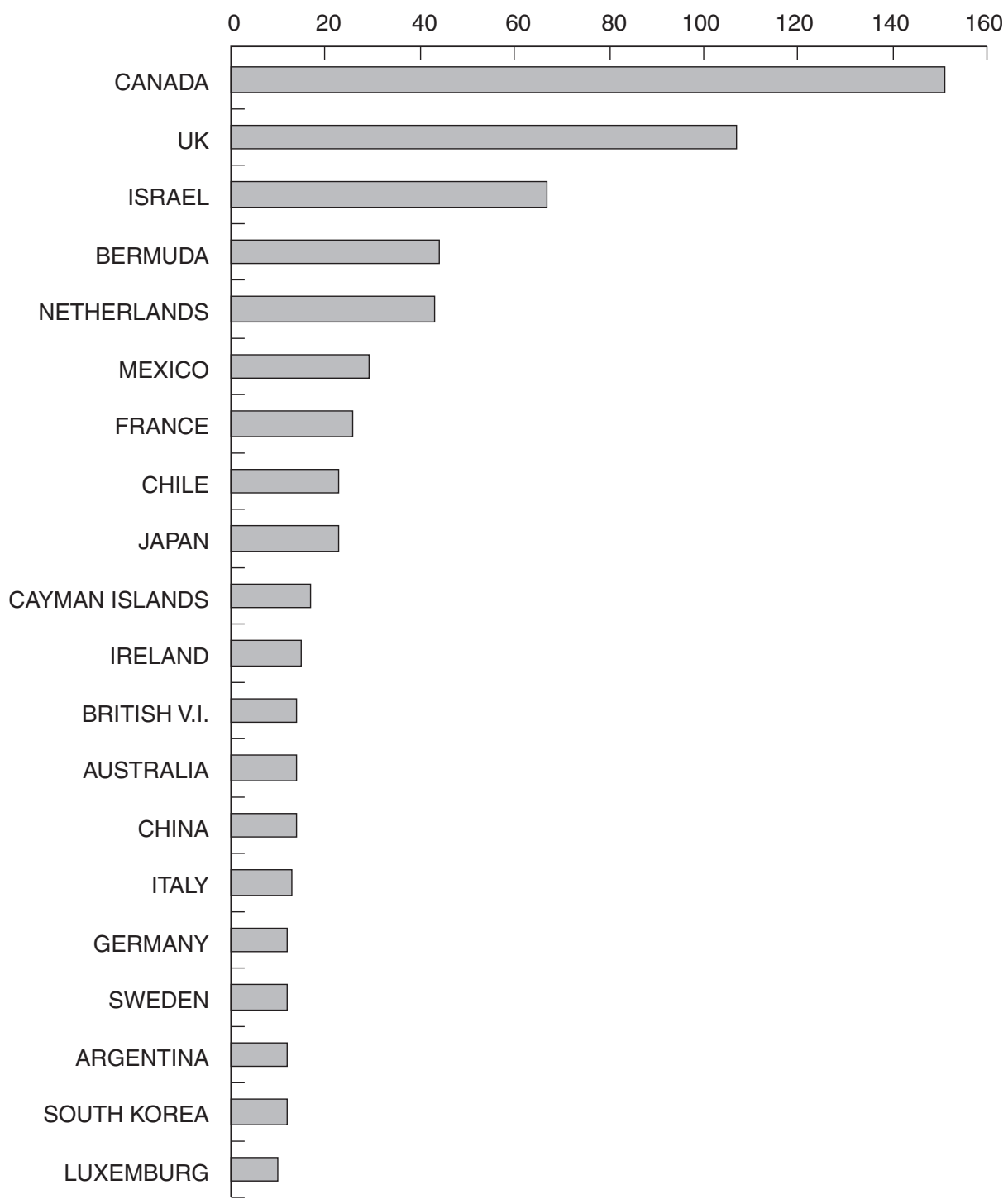

Figure 2 Largest sources of U.S. listings (by Nation of Incorporation).

currency. They also provide a relatively easy way for foreign issuers to access the U.S. capital markets (see Velli 1994 for an overview). The primary cost for a foreign issuer is that it must file audited annual financial statements with the SEC that conform to GAAP (or equivalent) accounting standards and must furnish reports of information provided to security holders or 
domestic regulators (see Coopers \& Lybrand 1999). It also becomes subject to other U.S. securities laws, including the ownership disclosure and takeover regulations of the Williams Act. Those owning more than 5 percent of a U.S.-listed firm's shares, or those seeking to take over such a firm, are required to file with the SEC even if both they and the target firm are domiciled outside the U.S. Potential acquirers of foreign issuers are bound by the procedural rules governing takeover bids, which are intended to ensure fair treatment of minority shareholders. U.S.-listed firms are also bound by the Foreign Corrupt Practices Act and by Rule 10b-5, allowing shareholders to sue for losses based on fraudulent statements made by management (see Coffee 1999).

The demands imposed by a U.S. listing suggest a plausible firm-level argument for convergence. Corporations that voluntarily list on a U.S. market are opting into a strict set of laws and regulations designed to protect the interests of (American) investors. As a result, they generally get higher valuations than comparable firms that are not subject to these laws do (Licht 1998). Coffee (1999) argues that such firms are more likely to survive imminent global industry consolidations because their higher valuations make them more costly to acquire and give them a valuable currency to make acquisitions. Owners of acquisition targets are more likely to accept payment in shares of U.S.-listed firms than in shares of firms listed only in France or Japan, and therefore foreign corporations intending to make substantial global acquisitions have incentives to list in the U.S. Daimler Benz represents one possible case of this process, listing on the NYSE in 1993 and acquiring Chrysler in 1998. At present, U.S.-listed firms include Vodafone, Deutsche Telecom, France Telecom, British Telecomm, and Nippon Telegraph \& Telephone-among the world's largest telecom firms - as well as many of the largest global auto, pharmaceutical, oil, and electronics companies. These firms have, in effect, opted in to American securities laws without having either to reincorporate in the U.S. (which is impractical for many established firms) or to change domestic laws to conform. Thus, nations need not seek to become "more American" for their indigenous firms to converge on American-style governance. This suggests that if firm-level convergence is happening anywhere, it should be among U.S.-listed foreign firms. By contrast, if U.S.-listed firms are not adopting American governance practices, we should be able to falsify (at least tentatively) the strong account for convergence.

There are two difficulties with an approach that assumes that corporate managers unproblematically recognize and act on the incentives for institutional migration, and that a U.S. listing represents opting in to the larger system of shareholder capitalism. First, the relevant actors are relatively large corporations for whom choice processes at the board level are subject to a number of influences that may stand in the way of voluntary conformity. If demonstrating fitness to investors were the motivation for 
listing in the U.S., then firms from nations with a French civil law tradition have much greater incentives to do so because of the relatively poor investor protections encoded in their domestic laws (Reese and Weisbach 2000). Yet by far the largest number of foreign firms on U.S. markets come from Canada, Great Britain, and Israel (accounting for nearly 40 percent of foreign listings) — each of which has investor-friendly common law (see figure 2). Second, shareholder capitalism as a style or genre of corporate governance entails a set of shared understandings of how business is done that go beyond disclosure requirements, and as such it is "as American as a Faulkner or Hemingway novel" (Davis and Useem 2001). Such shared understandings are not part of securities regulations or the NYSE listing agreement but underlie the governance practices of the U.S. corporation. Both these elements were exemplified by German steelmaker Krupp-Hoesch's takeover bid for rival Thyssen in March 1997. The hostile bid was decried as American-style "cowboy capitalism" and prompted massive street protests and high-level political intervention. Krupp's CEO Cromme was pelted with eggs and tomatoes by laborers fearing job cuts, and the bid was ultimately withdrawn in favor of a negotiated joint operating agreement. At the time, Gerhard Schroeder (then premier of Lower Saxony and a board member of Volkswagen) publicly welcomed the prospect of Cromme's joining VW's supervisory board so he could be "re-socialized" (Shroeder's term) into the German way of doing business (Deutsche PresseAgentur 1997). "Issuer choice" is evidently not the autonomous process that law and economics scholars portray.

\section{An Organizational Theory Approach to Studying Governance Convergence}

As the Krupp-Thyssen case shows, issuer choice is "embedded and enmeshed" in larger social processes that shape the evolution of governance structures and institutions. Individual firms may not be as institutionally footloose as the imagery of issuer choice implies, and even firms that elect to list shares in the U.S. may not be willing or able to adapt the full slate of governance reforms associated with shareholder capitalism. At the center of this question is the board of directors-it is both the locus of toplevel corporate decision making about governance reform and its object. Codes of good corporate governance have proliferated during the past few years (see http://www.ecgn.ulb.ac.be/ecgn/codes.htm for several), and behind all these codes are the assumptions that (1) boards of directors are ultimately responsible for the direction of the corporation and (2) the appropriate guiding principle for board decision making is attentiveness to shareholder value as an ultimate criterion. 
The first assumption is only moderately controversial, the second one wildly so. Indeed, by law and custom, corporate boards around the world reflect very different notions of the role of the corporation in society and the range of constituencies whose interests ought to be reflected in the board's makeup (see Charkham 1994). Possibilities range from the communitarian view, in which corporations are social entities with obligations to labor, capital, and broader communities, to the contractarian view, in which corporate decision making should be entirely driven by what is best for residual claimants (see Davis and Useem 2001). Activist institutional investors take the latter view (unsurprisingly) and argue that boards should be as small as is practical (because large boards promote passivity among directors) and there should be large majority of "independent" directors (not executives of the firm or others with potential conflicts that might impede their shareholder orientation). U.S. boards are relatively small (about nine members) and contain few executives (two on average), and the CEO is also Chair in more than three out of four firms. The small size and numerical dominance of outside directors in the boards of large firms is consistent with the preferences of the institutional investors that hold most of their equity. Very similar size and composition figures hold for French corporate boards; however, French boards are also densely connected by a network of shared directors who were often "old boys" of the Ecole Nationale d'Administration (Kadushin 1995), perhaps reflecting a cultural view of the necessary background for corporate oversight (Dobbin 1994).

The size of German supervisory boards (Aufsichtsrat) is keyed by statute to the number of employees (ranging from 12 to 20 for large firms), and half the directors represent labor, while by tradition banks are represented among the "shareholder" directors-in contrast to the U.S., banks traditionally held substantial ownership blocks of the largest public firms in Germany. Thus, both capital (banks) and labor are traditionally represented in the governance of German public corporations. Japanese boards are huge (averaging 19 for all public companies, and from 30 to 40 for the largest firms) and dominated by executives of the firm (roughly $80 \%$ insiders on average), arguably reflecting the notion that a broad sampling of the firm's managers best represent the interests of the organization qua organization. And British boards have similar sizes but very different structures than U.S. boards, with half the directors being "insiders" and the Chair generally being separate from the CEO (see Charkham 1994 and Hopt et al. 1998 for broad overviews of each of these systems).

In each of these cases, the governance structure of the typical firm reflects a view of the corporation's place in society, and to whom it is responsible. Thus, signs of governance convergence at the organizational level would be reflected in moves from traditional patterns of board structure toward the American pattern: relatively small boards numerically dominated by 
outsiders. But as Stinchcombe (1965: 161) put it long ago, for an organizational form such as the public corporation to survive, it "must have an elite structure of such a form and character that those people in the society who control resources essential to the organization's success will be satisfied that their interests are represented in the goal-setting apparatus of the enterprise." Moreover, the processes used to legitimize these authority structures tend to institutionalize them in a particular form that reflects the social conditions at the time and place of their founding: they become "infused with value ... an institution rather than a dispensable technical device" (167). The Krupp-Thyssen case illustrates some of the social and political forces at work in maintaining institutionalized governance practices. Thus, we may consider Stinchcombe's account to suggest a null hypothesis: governance structures will typically follow well-established traditions reflecting the interests of power-holders; firms listing shares in the U.S. will not come to look appreciably different than their domestic peers. To the extent that U.S.-listed foreign firms adopt American-style corporate governance, it will be among new firms, not established ones.

Yet while the case for inertia in corporate governance is suggestive, there are other plausible theoretical accounts that suggest devices militating toward homogeneity in organizational practices. Each account suggests empirical traces that we can investigate.

Anticipatory Socialization. The simplest account would be that nonU.S. corporations already have U.S.-style governance structures upon entry to the U.S. system. Such firms would adopt a package of governance reforms as a group in response to the incentives residing in financial markets. This can take two forms: either the kinds of firms that list on Nasdaq or NYSE are those that already have U.S.-style governance structures (and thus a U.S. listing is not causal), or firms that expect to list in the U.S. adopt such structures in anticipation. This is the strongest version of the convergence hypothesis, and suggests that foreign firms would be effectively indistinguishable from U.S. firms, at least structurally. Firms listing in the U.S. range from former state-owned phone companies, to venerable auto manufacturers (including DaimlerChrysler, Honda, Toyota, Volvo, Fiat, and Brilliance China Automotive Holdings), to newly-minted software and biotech firms. While the time-stamping hypothesis would lead us to expect such types of firms to retain the governance structures they had upon founding, the strong convergence thesis sees them as moving swiftly to the American standard. This is most consistent with the process described by Useem (1998) and Coffee (1999).

Networks and Corporate Governance. In between these all-or-nothing hypotheses are approaches that point to the specific cogs and wheels 
responsible for governance change (cf. Hedstrom and Swedberg, 1998). Neo-institutional theory highlights the role of networks in the spread of practices and in processes of homogenization (DiMaggio and Powell 1983). Thus, for instance, within-nation networks among businesses such as the keiretsu in Japan and the grupos economicos in Latin America reinforce local models of governance (Granovetter 1994). Perhaps the most important network for understanding corporate governance is the interlock network created by shared directors. Interlock networks within nations have been studied in the U.S., Canada, France, the UK, Germany, the Netherlands, and elsewhere (see Stokman et al. 1985 for a collection). In the U.S., the vast majority of large corporations are tied into a single network created by overlapping board memberships. This network has "small world" properties, in the sense that the shortest path between any two firms created by shared directors is quite small, averaging about 3.5 "degrees of separation" among the 1000 largest U.S. firms, and about 4.5 degrees of separation among their 7000+ directors (Davis et al. 2003). There is now a large literature documenting the role of board interlocks in the spread of governance practices such as adopting a poison pill (Davis and Greve 1997), creating an investor relations office (Rao and Sivakumar 1999), making particular types of acquisitions (Haunschild 1993), and others. In each case, directors who have experience with the practice under consideration are especially influential in board discussions of its merits. Rao et al. (2000), for instance, show that Nasdaq-listed firms are particularly likely to re-list on the New York Stock Exchange when they share directors with other Nasdaq firms that relist, a sort of "chain migration" process familiar to Nasdaq officials. To the extent that there is a "culture of the boardroom," shared directors serve a crucial role in transmitting it across firms, and the network they create is an ideal substrate for contagion processes.

Although the internationalization of U.S. and European firms was well underway by the 1970s, their boards were still remarkably domestic in orientation-particularly those of American corporations. Fennema and Schijf (1985) studied interlocks among the 40 most central corporations in the U.S. and each of several Western European nations in 1976 and found only six ties between American and European businesses. (There was modestly more overlap among the boards of European companies.) There were, in short, few channels for the sort of cultural understanding of corporate governance we have described; each nation's network was relatively selfcontained, reinforcing local practices. But the explosion of U.S. listings in the 1990s opens up the prospect for a more expanded cross-national network, and with it a mechanism for the spread of governance practices among firms across borders. To the extent that foreign firms are tied to U.S. firms, we might expect their governance practices to converge toward the American model. 
Convergence over Time. Finally, governance change may be more evolutionary and occur over time through exposure. This suggests that foreign firms would continue to reflect their country of origin upon listing, but would come to look more American the longer they were listed on U.S. markets.

As indicated by figure 1 , it is still quite early in the process, and we cannot expect much settlement. At best we might be able to falsify the hypothesis of strong convergence and give some sense of what to expect going forward. Thus, we ask: (1) What distinguishes U.S.-listed foreign firms that share directors with American firms? (2) What effect do size, country of origin, listing time, and U.S. ties have on discretionary choices (the size of the board, the proportion of insiders, whether the CEO holds the Chairman title, and disclosure)? and (3) What impact do U.S. ties and national origin have on investor and analyst recognition and the degree of ownership concentration?

\section{Methods}

\section{Sample}

We gathered data on every corporation listed on the New York Stock Exchange and Nasdaq in August 2000 that had filings available through Disclosure, which contracts with the SEC to make filings publicly available. The population included 2040 firms on NYSE (1658 U.S. firms) and 3841 Nasdaq firms (3466 U.S.). The most relevant information for our purposes was the composition of the board of directors, which U.S. firms report annually on their $10 \mathrm{~K}$ and proxy statement and which foreign firms report annually on form 20F. We assembled information on 47,349 directors serving on 5,627 boards, and from this derived a number of other measures (board size, proportion of "insiders," separation of the positions of CEO and board chair, and the other boards the directors served on). The minimum criterion for inclusion in our final sample was the availability of data on the board of directors. Our sub-samples included 72 firms from the United Kingdom, 24 firms from France, 12 from Germany, 59 from Israel, 23 from Chile, and 20 from Japan. Disclosure is the most comprehensive source of data from current SEC filings; thus, availability of board data from this source is an appropriate criterion for defining the study population of "U.S.-listed firms at risk of adopting American-style governance practices."

We selected firms from these countries for several reasons. First, excellent data on patterns of domestic corporate governance structures and board of director networks are available on the UK, France, Germany, and Japan (e.g., Charkham 1994; Wymeersch 1998; Stokman et al. 1985). This provides a 
baseline against which to compare the governance of U.S.-listed firms from those nations. Corporations from these nations and the U.S. are also those that are most prevalent in the global economy. Second, Chile and Israel each provide interesting but less-studied cases. Chile has undergone a series of free-market economic reforms, including a significant overhaul of its pension system (see Khanna and Palepu 2000). This has resulted in a partial unwinding of traditional business networks and the listing of nearly two dozen domestic corporations on the New York Stock Exchange. Israel now provides the third-largest number of foreign firms listed on U.S. markets (after Canada and the UK), and listing on Nasdaq (rather than the Tel Aviv Stock Exchange) has become the exit strategy of choice for high-tech firms in Israel (Rock 2001). Moreover, as our results indicate, Israeli firms are largely indistinguishable in their governance structures from U.S. firms listed on Nasdaq — an informative anomaly, as it turns out.

\section{Data}

Measuring convergence in corporate governance is problematic at the national level but somewhat more tractable at the firm level. We sought multiple indicators of two constructs: "governance practices" and "investor recognition." The size and composition of the board are relatively discretionary choices that show great variation across national systems (see Charkham 1994). By world standards, American boards are small relative to the size of the companies they represent: the board of the median NYSE-listed U.S. firm had nine directors, while Nasdaq boards had seven members on average. Convergence in board size would be represented by a relatively small board. The boards of U.S. firms also typically have a large proportion of outside (non-executive) directors. We measured the percentage of insiders as the proportion of directors that were currently officers of the corporation; convergence would be indicated by having a relatively small proportion of insiders. (Practically speaking, it was not possible to determine the proportion of "affiliated" outside directors on a large and multinational sample using public data.) We created an indicator variable for whether the CEO also held the position of Chairman of the Board. In the large majority of major U.S. firms, one person holds both positions; thus, convergence would be indicated by one person holding both slots.

Our final board measure is the number of board ties to U.S. corporations created by shared directors. We again started with the directors of all firms traded on Nasdaq and NYSE in Fall 2000, a group of over 38,000 directors occupying over 47,000 directorships. We used both computerized routines and hand-checks to verify that directors were identified unambiguously (i.e., different directors sharing the same name were identified separately, using data on their ages) and correctly (i.e., directors' names 
were rendered consistent across the different boards on which they served). Our primary variable of interest from this dataset is simply the number of boards of U.S. firms that each of our sample firms shared directors with. For example, Peter Magowen, a DaimlerChrysler director, also served on the boards of Safeway and Caterpillar, thus creating two "U.S. ties" for DaimlerChrysler. We also turned the board network data into a matrix to calculate a number of other network measures.

In addition to the board-based measures of conformity, we used another indicator of a discretionary choice, namely, does the firm make its 20F SEC filings available via EDGAR (the SEC's Electronic Data Gathering and Retrieval system). Under Regulation S-T, all domestic filers are required to submit all documents electronically, and most (including proxy statements and annual reports) are subsequently made available publicly via the Web. Foreign private issuers and foreign governments are not subject to this requirement, but they may choose to file electronically as well. We take electronic filing of the $20 \mathrm{~F}$ to be an indicator of attentiveness to investors. Among our 209 sample firms, only 46 (22 percent) filed 20Fs electronically.

We also counted the number of $6 \mathrm{~K}$ filings by each firm per year as an indication of the expansiveness of the firm's disclosure. Although all foreign private issuers are required to file $20 \mathrm{Fs}$ annually, they have some discretion over the other information they file with the SEC. Other items are filed with form $6 \mathrm{~K}$, including information "(i) required to be made public in the country of its domicile; (ii) filed with and made public by a foreign stock exchange on which its securities are traded; or (iii) distributed to security holders" (Securities and Exchange Commission). Typically these filings are press releases made by the company to announce events that are material to investors, such as mergers, changes in executives, and so on. What is "material," however, is not exhaustively defined by the SEC. For example, Arel Communications and Software (an Israeli firm) includes among its $6 \mathrm{Ks}$ the following press releases: "France Telecom's FCR subsidiary launches hyperfax service with Arelnet's I-Tone"; "Arel to provide interactive distance learning system for Good Samaritan Society", "Volkswagen of America selects interactive distance learning system from Arel"; "Arel raises \$4 million from exercise of Series A warrants"; "Bob Jones University selects interactive distance learning system from Arel"; and so on. We take the number of 6Ks to indicate a firm's approach to disclosure, with more extensive disclosure indicating a more American approach.

Other variables included in the models are size (measured as the market value of common equity in August 2000, and alternatively as the number of employees worldwide and annual sales volume); country of origin (we include dummy variables for Chile, Germany, France, Israel, and Japan; United Kingdom was the omitted category); time listed on a U.S. stock 
market (in days); and the stock market on which the firm was listed (a dummy variable for NYSE). Based on Stinchcombe's (1965) arguments, we also took account of the age of the firms' primary industry by including a set of dummy variables (for computers, communications equipment, electronic components, software and information processing, and biotech). In our sample of 209 firms, 63 were in these industries, with software accounting for 37 of them.

We were also interested in the degree to which foreign issuers received recognition from investors. Investor recognition is both an outcome of shareholder-oriented governance and an additional source of scrutiny and influence with respect to governance practices. Securities analysts and institutional investors (such as public pension funds) form a sort of Greek chorus for corporate management, examining their management and governance practices and offering (often unbidden) advice (Useem 1996). Firms that attract more analysts subsequently achieve higher average valuations, and firms with more extensive disclosures attract more analysts and more institutional ownership (see Davis and Useem 2001 for a review). To the extent that non-U.S. firms list on American stock markets as part of a program oriented toward shareholder value, then larger analyst followings and more extensive interest from institutional investors are indications of success. We included two measures of investor recognition. First, the number of analysts following a firm was the count of those issuing earnings estimates reported by $\mathrm{I} / \mathrm{B} / \mathrm{E} / \mathrm{S}$ in 2000 . I/B/E/S gathers information from over 7000 securities analysts working at more than 1000 investment houses (and covering 18,000 companies) around the world. (Although purportedly global in scope, $\mathrm{I} / \mathrm{B} / \mathrm{E} / \mathrm{S}$ analysts disproportionately represent North American financial institutions.) The more analysts following a firm, the more it is on the radar screen of significant investors (Rao et al. 2001). Second, data on institutional ownership (as a proportion of a firm's outstanding shares) came from $13 \mathrm{~F}$ disclosures, which the SEC requires of any entity owning more than $\$ 100$ million in equity capital. These are overwhelmingly American (and to a lesser extent British) financial institutions, mutual funds, and pension funds. The magnitude of a firm's $13 \mathrm{~F}$ ownership is a direct measure of success at attracting investor interest.

Finally, we examined the size of the firm's single largest ownership block. While the original discovery of the separation of ownership and control lamented the consequences of dispersed ownership (Berle and Means 1932), more recent research has emphasized that dispersed ownership is a positive achievement for a national system of corporate governance. By hypothesis, dispersed ownership only arises when a nation's law and institutions of corporate governance are well developed for protecting the interests of minority shareholders. When legal protections for minority shareholders are weak (or not well-enforced) and monitoring devices 
are not well developed, businesses tend to be privately held, and those corporations that are publicly traded tend to have highly concentrated ownership, with the single largest ownership block often passing 50 percent (LaPorta et al. 1999). Around the world, ownership of the largest firms tends to be dispersed in common law countries with strong investor protections and concentrated in countries with civil law. If a U.S. listing is sufficient to bring a broad array of investor protections via American securities laws (Coffee 1999), then we should expect levels of ownership concentration to be lower among U.S.-listed firms than those not listed in the U.S. The size of the largest ownership block was calculated using $13 \mathrm{D}$ and $\mathrm{l} 3 \mathrm{G}$ filings, which are required of all owners of 5 percent or more of a U.S.-listed corporation's voting securities (regardless of their nationality).

We note several limitations at this point. First, because all the measures were contemporaneous, it is impossible to draw strong causal inferences. About 60 percent of the firms we studied first listed on U.S. markets in 1995 or later, and only about $20 \%$ listed prior to 1990 (see figure 1). Thus, because the events we study are so recent, a time-series study that might partial out the temporal ordering of them was effectively impossible. Second, our ultimate outcomes (investor recognition and ownership concentration) are of course endogenous: there is a cycle between the quality of disclosure, level of analyst following, ownership by institutions, and governance reform. Better-run firms with higher-quality disclosure may attract more institutional investors, while institutional investors and analysts exert pressure for better governance and disclosure. Although we cannot verify a causal account, it is nonetheless possible in principle to falsify the strongest account of convergence and to document which factors move together.

\section{Models}

We used a variety of statistical methods, according to the question being asked. For modeling the number of board ties to U.S. firms, the size of the board, number of $6 \mathrm{~K}$ filings, and the size of analyst following, we used negative binomial regression. This model is appropriate for count data where dispersion is likely to be too large to be consistent with the assumptions of the Poisson model. For modeling whether the firm split the positions of CEO and board chair, and whether the firm's filings were available via EDGAR, we used logistic regression. For examining the size of the largest known ownership block, we used Tobit. This model is appropriate when the outcome variable is censored (i.e., the value is unobserved above or below a certain level); in this case, owners are only required to report their stake if it exceeds 5 percent, and we thus used 5 percent as a cut-off level. 
Finally, for institutional ownership, we used ordinary least squares regression. (Although strictly speaking percentages are bounded and thus violate the assumptions of OLS, we believe this violation is harmless in this case.)

\section{RESULTS}

Table 1 shows a correlation matrix for the primary variables studied. Several things are notable. Larger firms (as measured by sales or market capitalization) tend to have larger boards and are more likely to be listed on the NYSE, as one would expect. There are substantial correlations among national origin and the various measures of governance. And we find significant intercorrelations among board ties to U.S. firms, market capitalization, size of analyst following, volume of disclosures (as indicated by the number of $6 \mathrm{Ks}$ ), and accessibility of disclosures (filing via EDGAR). In contrast to market capitalization, size measured by sales has a small or negative correlation with disclosures, analyst following, and U.S. board ties.

Table 2 compares U.S. firms listed on NYSE and Nasdaq with their counterparts in the UK, France, Germany, Japan, Israel, and Chile. The averages are quite consistent with the reported averages for domestic companies in each of these places. Tricker (1998), for instance, reports that among UK corporations, the average board size is 12 , of whom 50 percent are insiders; in 90 percent of firms, the CEO and the Chair are different persons. Wymeersch (1998: 1107, 1113) reports an average board size of 10 and 84 percent with a split $\mathrm{CEO} / \mathrm{Chair}$. We find an average board size of 10,50 percent insiders, and 92 percent with a CEO/Chair split. U.S. firms listed on NYSE average 9 persons on the board, 22 percent insiders, and only 35 percent with a split CEO/Chair. In short, the average U.S.listed British firm is much more similar to its domestic counterparts than to American firms.

French boards average 13 members, of whom 18 percent are insiders, and the Chair is almost universally the CEO (Tricker, 1998; Wymeersch, 1998). We find an average size of 10, 20 percent insiders, and in 76 percent a unified CEO/Chair. As shown in figure 3, we also find dense interlocks among large French corporations listed on U.S. stock markets. Indeed, French firms on NYSE_-which tend to be relatively large and well established-interlock almost exclusively with other French firms or U.S.based French subsidiaries. In contrast, high tech French firms, usually listed in Nasdaq, are well connected to other high tech firms - often through venture capitalists on their boards.

German boards are somewhat more difficult to classify by the standards applied to U.S. corporate governance, as their size and composition have traditionally been regulated rather than left to the discretion of the board 
itself. The average board size of U.S.-listed German firms (12) is comparable to domestic firms (13). By our calculations, 17 percent of the average supervisory board members are current executives of the firm, and on 92 percent of boards separate persons hold the titles of CEO and Chair (see Hopt 1998; Prigge 1998 for comparable figures). Several German firms share directors with U.S. firms, as well as with firms from France, Japan, Norway, Israel, and Canada. As figure 4 shows, DaimlerChrysler accounts for about half the German firms' ties to U.S. boards, largely from former Chrysler directors who were retained on the board after Daimler acquired Chrysler in 1998.

Several Japanese firms have been listed on NYSE since the 1970s, and the figures in table 2 indicate that there has been little movement on average toward U.S. governance norms. The average U.S.-listed firm from Japan has 18 directors on the board (compared to 19 for all listed firms in Japan), of which 70 percent are insiders (vs. 77 percent in Japan), and 90 percent of boards are led by a Chairman other than the CEO-usually the prior CEO (see Kanda 1998 for descriptive data on Japanese boards). U.S.listed Japanese firms rarely share directors with other U.S.-listed firms, from Japan or elsewhere, except in the case of subsidiaries-see figure 5.

Chilean corporations present an interesting case. The median Chilean firm has no interlocks with any other U.S.-listed firms, and none of the nearly two dozen Chilean firms listed on the New York Stock Exchange shares directors with a U.S. firm (see figure 6). Given the historical significance of elite networks for the Chilean economy, it is surprising that U.S.listed firms are as disconnected as they are (Khanna and Palepu 2000). Chilean firms also attract very little interest from analysts or institutional investors.

Contrast this with Israeli firms. Nearly half the Israeli firms listed in the U.S. share directors with at least one U.S. firm, they have substantial analyst followings, and they attract significant interest from institutional investors. Most are listed on Nasdaq, most are in high-tech industries-particularly software-and a large number are funded by Silicon Valley venture capitalists, who typically serve on their boards (see Rock 2001). Many Israeli firm bypass the relatively anemic Tel Aviv Stock Exchange in favor of a primary listing on Nasdaq. Indeed, listing in the U.S. is the predominant exit strategy of venture capitalists funding Israeli firms; put another way, Nasdaq is largely accountable for the proliferation of new business starts in hightech industries in Israel. By most measures, these firms are effectively indistinguishable in the governance practices from American firms listed on Nasdaq. (The number of firms and density of ties makes graphs of the Israeli interlock network rather uninformative.)

In the aggregate, compared to U.S. firms, foreign firms listed on U.S. markets have significantly larger boards (mean of 10 vs. 8.3); more insiders 
Table 1

Correlation Matrix Among Variables

\begin{tabular}{|c|c|c|c|c|c|c|c|c|c|c|}
\hline & & 1 & 2 & 3 & 4 & 5 & 6 & 7 & 8 & 9 \\
\hline 1 & U.S. ties & & & & & & & & & \\
\hline 2 & $\begin{array}{l}\text { Board } \\
\text { size }\end{array}$ & 0.16 & & & & & & & & \\
\hline 3 & $\begin{array}{l}\text { Insider } \\
\%\end{array}$ & 0.01 & 0.09 & & & & & & & \\
\hline 4 & $\begin{array}{l}\mathrm{CEO}= \\
\text { chair }\end{array}$ & 0.05 & -0.13 & -0.16 & & & & & & \\
\hline 5 & $\begin{array}{l}\text { EDGAR } \\
\text { filer }\end{array}$ & 0.22 & 0.00 & 0.13 & 0.02 & & & & & \\
\hline 6 & $6 \mathrm{Ks}$ filed & 0.34 & 0.15 & 0.13 & -0.09 & -0.02 & & & & \\
\hline 7 & Analysts 0.58 & 0.16 & -0.07 & 0.15 & 0.10 & 0.29 & & & & \\
\hline 8 & $\begin{array}{l}\text { Institu- } \\
\text { tional } \\
\text { ownership }\end{array}$ & 0.01 & -0.21 & 0.06 & 0.09 & 0.16 & -0.13 & 0.14 & & \\
\hline 9 & $\begin{array}{l}\text { Market } \\
\text { capitali- } \\
\text { zation }\end{array}$ & 0.48 & 0.51 & 0.03 & -0.01 & 0.02 & 0.42 & 0.50 & -0.09 & \\
\hline 10 & Sales & -0.08 & 0.55 & 0.20 & -0.14 & 0.07 & -0.01 & -0.08 & 0.03 & 0.38 \\
\hline 11 & $\begin{array}{l}\text { NYSE } \\
\text { listed }\end{array}$ & 0.08 & 0.32 & -0.03 & -0.13 & -0.14 & 0.23 & 0.12 & -0.32 & 0.32 \\
\hline 12 & Chile & -0.16 & -0.13 & -0.18 & -0.16 & -0.15 & -0.09 & -0.05 & -0.16 & -0.15 \\
\hline 13 & France & -0.05 & 0.04 & -0.25 & 0.47 & -0.02 & -0.03 & 0.06 & 0.09 & 0.05 \\
\hline 14 & Germany & 0.04 & 0.14 & -0.16 & 0.00 & 0.08 & -0.09 & 0.04 & -0.06 & 0.08 \\
\hline 15 & Israel & -0.09 & -0.31 & -0.25 & 0.11 & -0.02 & -0.16 & -0.03 & 0.27 & -0.27 \\
\hline 16 & Japan & 0.10 & 0.55 & 0.41 & -0.14 & 0.11 & -0.07 & -0.16 & 0.07 & 0.22 \\
\hline 17 & $\begin{array}{l}\text { Time } \\
\text { listed }\end{array}$ & 0.26 & 0.43 & 0.17 & -0.14 & -0.07 & 0.11 & 0.22 & -0.08 & 0.31 \\
\hline 18 & Computers & -0.06 & -0.07 & 0.05 & -0.12 & 0.10 & -0.06 & -0.01 & 0.23 & -0.02 \\
\hline 19 & $\begin{array}{l}\text { Communi- } \\
\text { cations } \\
\text { equipment }\end{array}$ & -0.06 & 0.03 & 0.00 & 0.15 & -0.02 & 0.00 & 0.14 & 0.10 & -0.02 \\
\hline 20 & $\begin{array}{l}\text { Electronic } \\
\text { compo- } \\
\text { nents }\end{array}$ & -0.04 & -0.02 & -0.05 & 0.09 & 0.01 & -0.06 & 0.05 & 0.01 & -0.01 \\
\hline 21 & $\begin{array}{l}\text { Software } \\
\text { and info } \\
\text { processing }\end{array}$ & -0.03 & -0.29 & 0.02 & 0.16 & 0.18 & -0.11 & -0.09 & 0.04 & -0.18 \\
\hline 22 & Biotech & 0.05 & -0.02 & 0.09 & -0.04 & -0.04 & 0.01 & -0.06 & -0.04 & -0.03 \\
\hline
\end{tabular}




\begin{tabular}{llllllllllll}
\hline \hline 10 & 11 & 12 & 13 & 14 & 15 & 16 & 17 & 18 & 19 & 20 & 21 \\
\hline
\end{tabular}

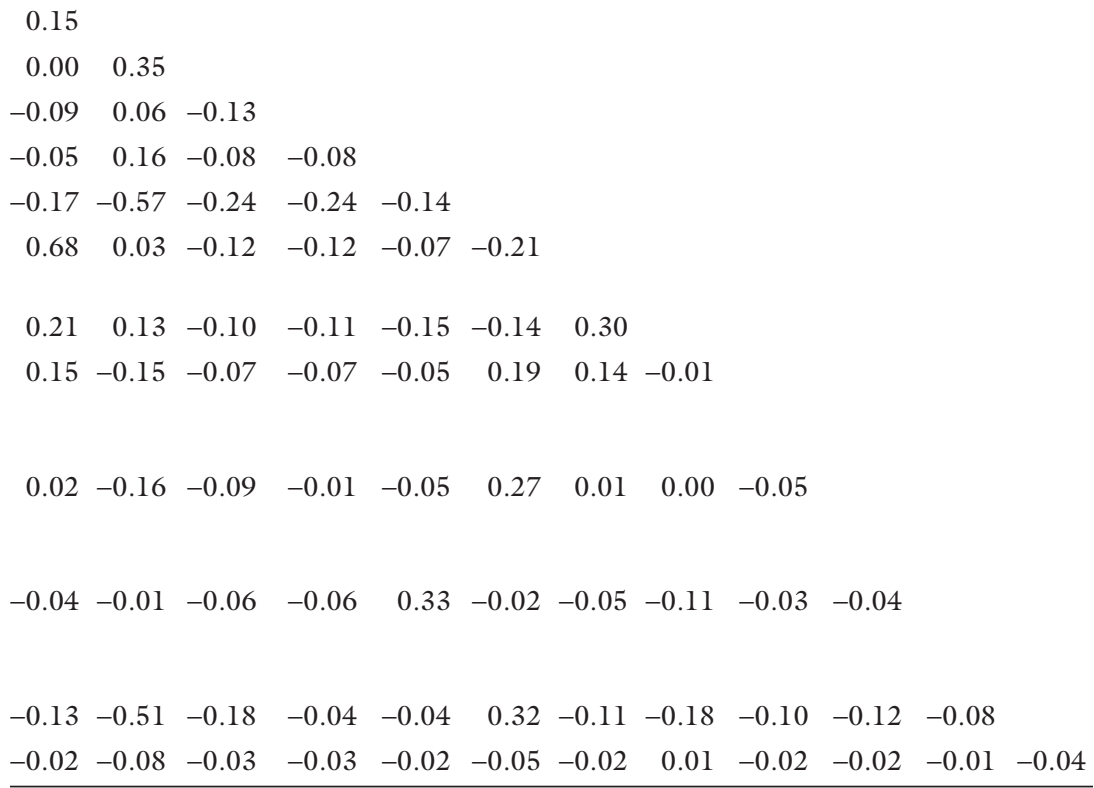


TABLE 2

Comparative Statistics on Corporations Listed on Nasdaq and the New York Exchange, Fall 2000

\begin{tabular}{|c|c|c|c|c|c|c|c|c|}
\hline & $\begin{array}{l}\text { NYSE } \\
\text { U.S. }\end{array}$ & $\begin{array}{l}\text { Nasdaq } \\
\text { U.S. }\end{array}$ & $U K$ & France & Germany & Japan & Israel & Chile \\
\hline $\begin{array}{l}\text { Number of } \\
\text { firms covered }\end{array}$ & 1695 & 3533 & 72 & 24 & 12 & 20 & 59 & 23 \\
\hline $\begin{array}{l}\text { Market } \\
\text { value }\end{array}$ & 1018 & 139 & 5194 & 2565 & 5175 & 26800 & 184 & 421 \\
\hline Employees & 5200 & 384 & 5178 & 3800 & 20450 & 35472 & 367 & 2626 \\
\hline $\begin{array}{l}\% \text { on } \\
\text { NYSE }\end{array}$ & & & 61 & 60 & 83 & 57 & 8 & 100 \\
\hline $\begin{array}{l}\% \text { owned by } \\
\text { largest } \\
\text { shareholder }\end{array}$ & 13 & 15 & 15 & 28 & 20 & 19 & 27 & 47 \\
\hline \# of analysts & 5 & 2 & 2 & 4 & 1 & 1 & 2 & 2 \\
\hline $\begin{array}{l}\% \text { owned by } \\
13 \text { F filers }\end{array}$ & 55 & 23 & 1 & 5 & 4 & 1 & 10 & 0.3 \\
\hline $\begin{array}{l}\text { Board } \\
\text { size }\end{array}$ & 9 & 7 & 10 & 10 & 12 & 18 & 7 & 9 \\
\hline$\%$ insiders & 22 & 33 & 50 & 20 & 17 & 70 & 29 & 25 \\
\hline $\begin{array}{l}\% \text { of firms } \\
\text { with split } \\
\text { CEO/Chair }\end{array}$ & 35 & 49 & 92 & 24 & 92 & 90 & 67 & 96 \\
\hline $\begin{array}{l}\text { Number of } \\
\text { interlocks }\end{array}$ & 6 & 2 & 2.5 & 3 & 2 & 1 & 2 & 0 \\
\hline $\begin{array}{l}\text { Board } \\
\text { ties to } \\
\text { U.S. firms }\end{array}$ & 6 & 2 & 1 & 0 & 1 & 0 & 0 & 0 \\
\hline $\begin{array}{l}\text { Mean \# } \\
\text { of outside } \\
\text { execs }\end{array}$ & 0.13 & 0.14 & 0.18 & 0.08 & 0.33 & 0.19 & 0.1 & 0.13 \\
\hline
\end{tabular}

Note: All figures are medians unless otherwise noted. Reported figures represent the largest sub-sample for which relevant data were available; thus, for example, if a firm had no $13 \mathrm{D}$ or $13 \mathrm{G}$ filings associated with it, it is not included in the calculation of "\% owned by largest shareholder." 


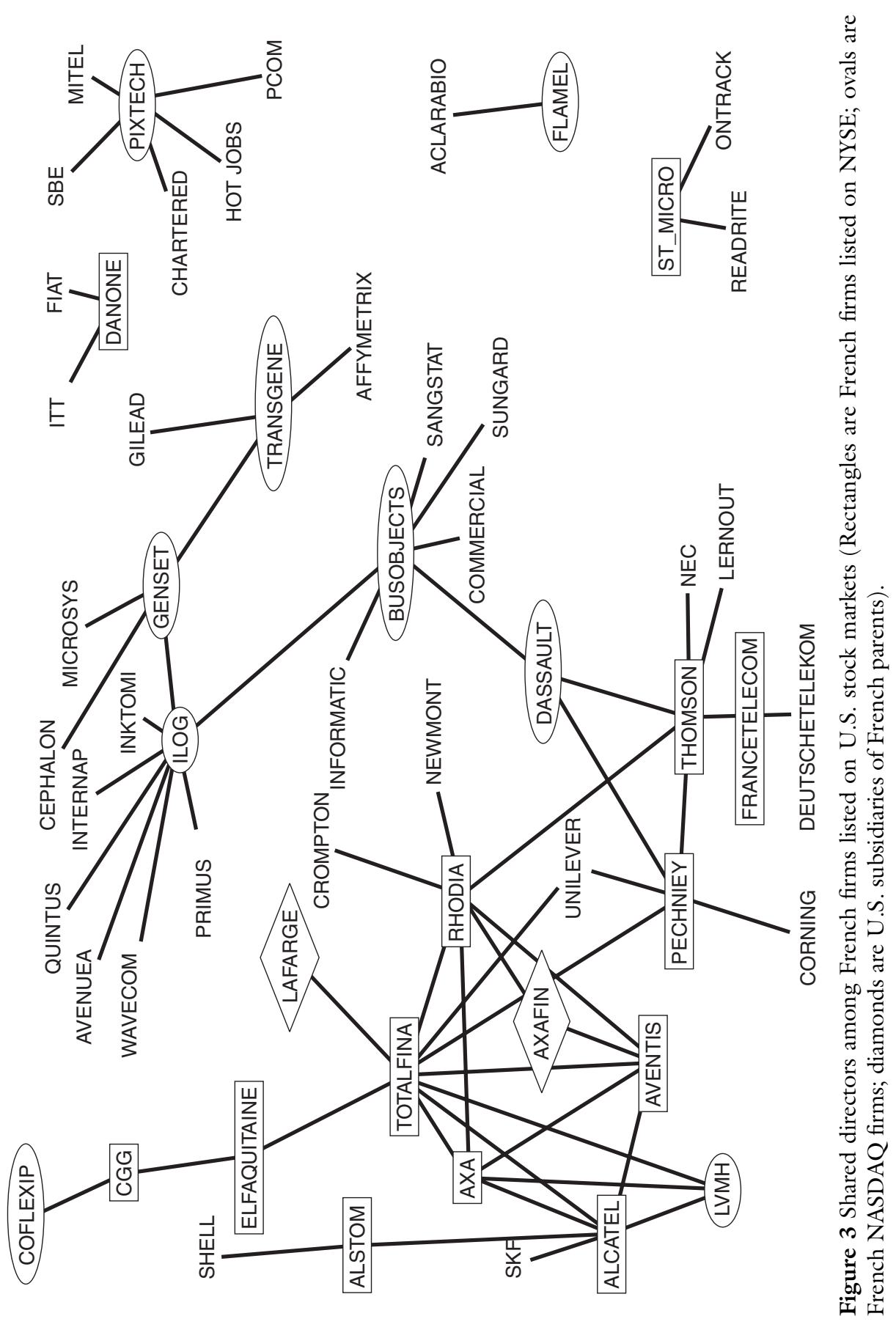



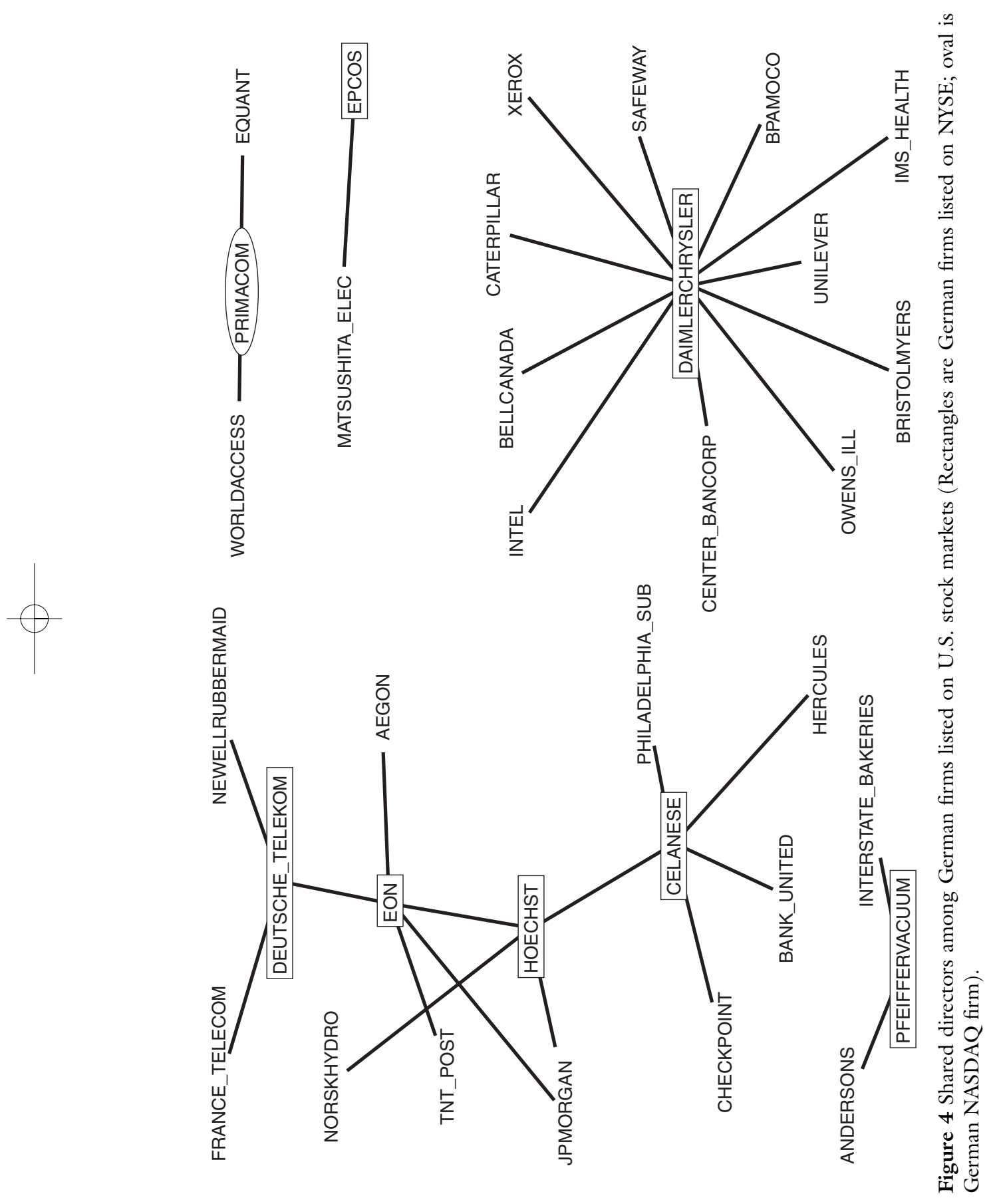

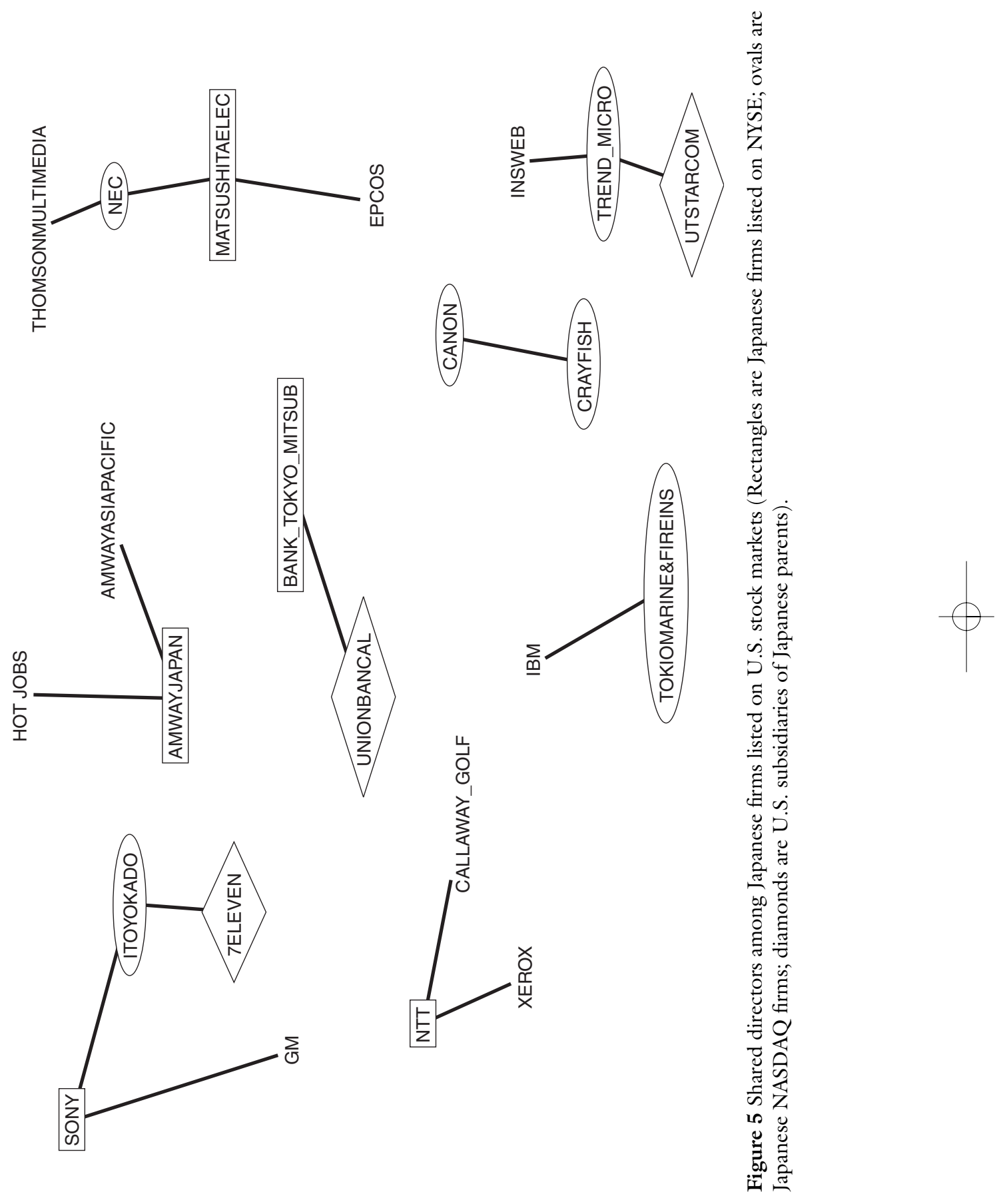

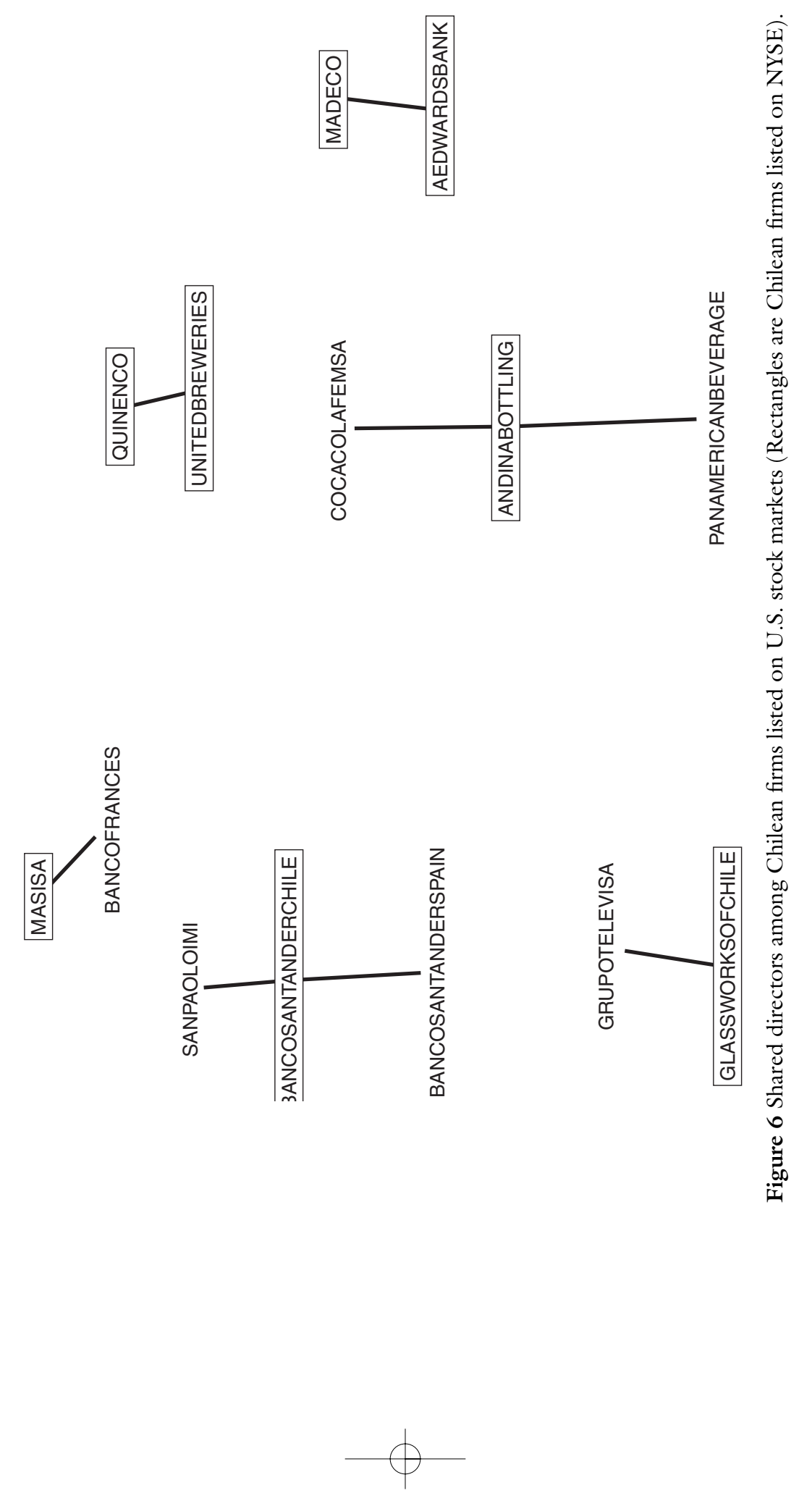
(34 percent vs. 31 percent), fewer analysts ( 3.3 vs. 4.8 ), lower institutional ownership (14 percent vs. 38 percent), and more concentrated ownership (23 percent vs. 19 percent, when the largest block is reported). (All these results hold when controlling for the market value of the firm's equity and the market on which it is listed). These results hold fairly broadly, with the notable exception of Israeli firms. Based on these findings, we can tentatively rule out the strongest convergence hypothesis-that firms listing on U.S. markets are indistinguishable from U.S. firms.

We next consider distinctions among firms listed on U.S. markets according to their level of network embeddedness. There is little doubt that there has been a substantial increase in cross-national interlock ties among boards of directors, albeit relative to a very small base among U.S. firms. Among the boards of the 40 most central (well-connected) American firms in the mid-1970s, Fennema and Schijf (1985) found only six international interlocks. In our data, we find 49 ties between the 40 most central U.S. firms and non-U.S. firms listed on U.S. markets; presumably there are even more ties to non-U.S. listed foreign firms. By far the largest number of ties are to British firms. BP Amoco, for instance, shared directors with 21 U.S. firms; most of these were legacies of the Amoco board retained after its acquisition by BP. Smithkline Beecham shared directors with 19 U.S. firms. These were exceptions, however: 58 percent of the non-U.S. firms in our sample had no board ties to U.S. firms, and 18 percent had only one. Yet foreign firms outside the Anglo-American system have incentives to appoint U.S. or UK directors. Randey and Oxelheim (2001) find that Norwegian and Swedish firms achieve higher valuations (as measured by Tobin's q) when they have British or American directors, above and beyond the effect achievable by listing on a foreign exchange. Whether American directors function simply as signals, or as conduits for governance norms and practices, it appears that they are perceived favorably by the stock market.

Table 3 examines the factors influencing the degree to which sampled firms shared directors with U.S. companies. The results show that, not surprisingly, large firms are more likely to share directors than small firms. Relative to firms from the United Kingdom (the omitted category in the models), firms from Japan and Chile were significantly less likely to have U.S. directors, while French and German corporations were no less likely to have U.S. directors. These differences are likely to reflect both the relative ease of travel between Europe and the U.S. (at least for directors of firms headquartered on the East Coast) and language ability (Conference Board 1999). Yet there are also substantial cross-national differences in the board network patterns that are not as easily explained by geography.

There is clearly a great deal of cross-national variation among U.S.-listed firms, both in their governance structures and in their degree of network 
TABLE 3

Correlates of Board Ties to U.S. Companies (Negative Binomial Regression)

\begin{tabular}{lrr}
\hline \hline & Coef. & \multicolumn{1}{c}{$Z$} \\
\hline Market value (millions) & 0.0130 & 3.26 \\
Listed on NYSE & -0.2752 & -0.83 \\
Chile & -3.1296 & -2.96 \\
Germany & 0.0147 & 0.03 \\
France & -0.3541 & -0.94 \\
Israel & -0.3438 & -0.97 \\
Japan & -1.5740 & -3.01 \\
Time listed in U.S. & 0.0001 & 1.35 \\
Computers & -0.7882 & -1.00 \\
Communications equipment & -0.4636 & -0.76 \\
Electronic components & -0.2391 & -0.35 \\
Software/info processing & -0.0132 & -0.04 \\
Biotech & 0.7175 & 0.74 \\
Constant & 0.2326 & 0.74 \\
n= $193, \chi^{2}=55.6$ & & \\
\hline
\end{tabular}

embeddedness. To what extent are these things related, and what is their impact on investor recognition? Table 4 reports analyses of the factors influencing governance choices. The first model analyzes the factors influencing board size among firms listed on Nasdaq and NYSE. Most firms had larger boards that U.S. firms listed on the same markets, and this is reflected in the results: larger firms and firms that had been listed on the U.S. market for longer tended to have larger boards on average, and French, German, and particularly Japanese firms had significantly larger boards than UK firms, even after controlling for firm size (sales, employment, and market capitalization). Chilean, German, French, and Israeli firms had proportionally fewer insiders on the boards than UK firms, while Japanese firms had significantly more (70 percent on average). French and Israeli firms were more likely that UK firms to have a CEO who was also Chairman of the Board. None of these three outcomes was affected by board ties to U.S. companies. In contrast, the firm's likelihood of filing documents with EDGAR, thus making them more readily accessible to investors, was significantly higher to the extent that its board shared directors with U.S. firms, and significantly lower the longer it had been listed in the U.S.. Interestingly, Japanese firms were more prone than other firms 


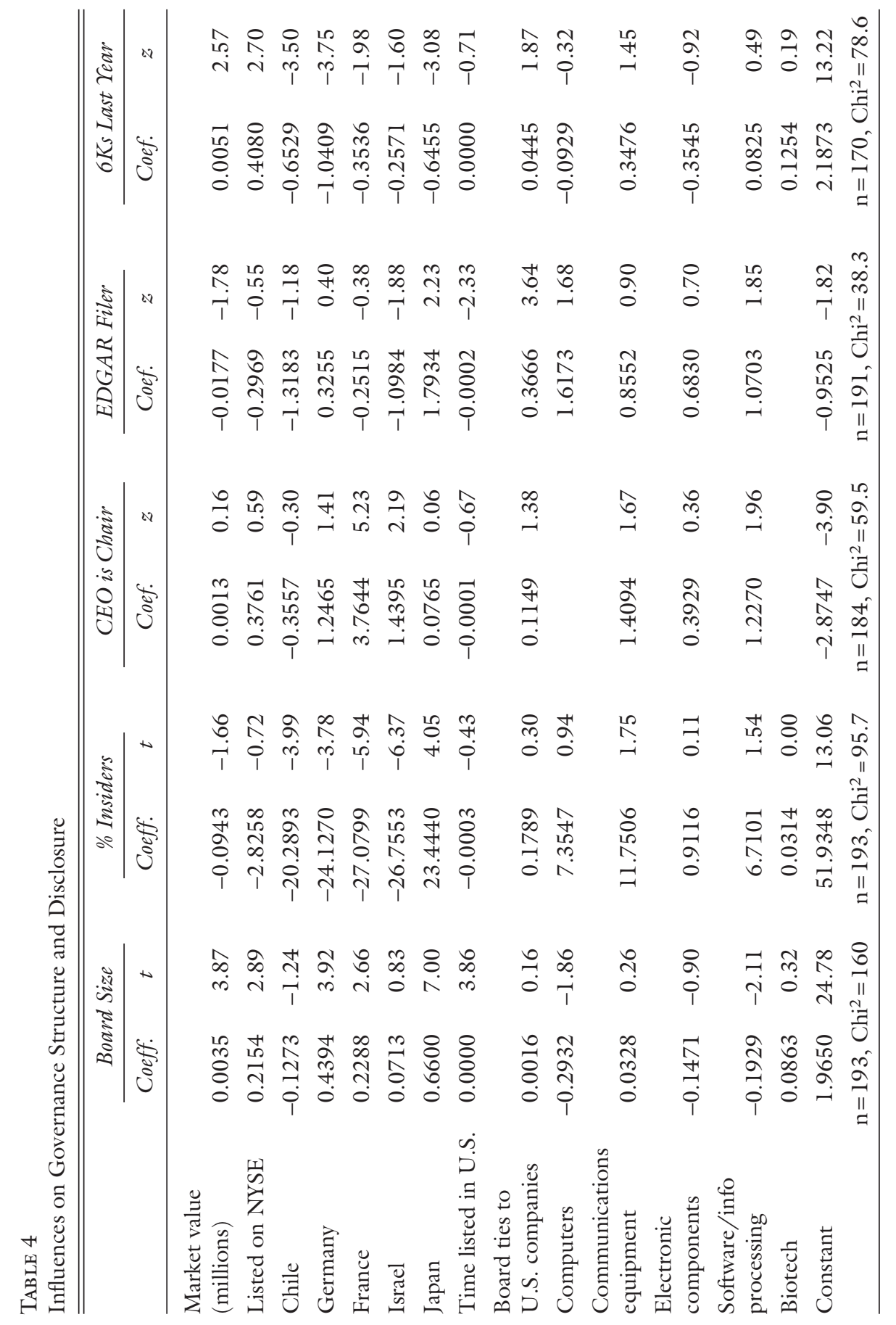


to filing electronically. Finally, the sheer volume of disclosures increased with firm size and a NYSE listing. Firms from the UK (the omitted category) filed substantially more disclosures than firms from the other nations, and ties to U.S. firms had a borderline significant positive relation with the volume of disclosures. Overall, these results are consistent with the argument that cross-national variation in governance persists even among U.S.-listed firms.

We also considered three aspects of investor recognition, reported in table 5. Analyst following is positively associated with a firm's size, as one would expect. Controlling for size, Israeli firms have significantly larger analyst following than UK firms, while Japanese firms have substantially smaller analyst followings. We also find that analyst following increases with the number of board ties to U.S. firms. Firms get roughly one more analyst for every two U.S. firms with which they share directors. We also find that analyst following is the only outcome for which our set of industry indicators had a significant collective effect-in other words, technology firms attracted greater analyst attention than firms in other industries from these six countries, as indicated by a likelihood ratio test. Institutional ownership is higher among French, Israeli, and Japanese firms than comparably-sized UK firms. Finally, we find that the size of the largest ownership block is larger among firms from Chile, France, and Israel relative to firms from the UK, and that the size of this block declines with the amount of time the firm has been listed in the U.S.. We note that this result should be treated with considerable caution. The Tobit model we report assumes that values below 5 percent (the reporting threshold under section 13d) are censored, or - put another way-if we do not have data on the largest ownership block, then its true value is below 5 percent. But while in principle foreign owners of foreign issuers may be required to disclose their ownership stakes to the SEC (see Coffee 1999), in practice we suspect that compliance outside the U.S. is low. Of these firms 32 percent had no data available on large blockholders, and 45 percent of those entities reporting a large holding were American firms or individuals, which is rather implausible. Put another way, it appears unlikely that one can use U.S. securities disclosures to ferret out the true ownership structures of foreign issuers.

\section{Discussion}

Our findings show substantial variation across nations in the propensity to appoint U.S.-based directors, in patterns of corporate governance and disclosure, and in the level of investor recognition, even among U.S.-listed foreign firms. The interlock networks among firms from Chile, France, 
TABLE 5

Influences on Investor Recognition

\begin{tabular}{|c|c|c|c|c|c|c|}
\hline & \multicolumn{2}{|c|}{ Analyst Following } & \multicolumn{2}{|c|}{ Institutional \% } & \multicolumn{2}{|c|}{ Largest Owner \% } \\
\hline & Coef. & $z$ & Coef. & $t$ & Coef. & $t$ \\
\hline $\begin{array}{l}\text { Market value } \\
\text { (millions) }\end{array}$ & 0.0086 & 2.81 & -0.0384 & -0.72 & -0.2404 & -1.70 \\
\hline $\begin{array}{l}\text { Listed on } \\
\text { NYSE }\end{array}$ & 0.2206 & 1.01 & -8.9474 & -2.33 & 13.0790 & 1.70 \\
\hline Chile & 0.2980 & 1.12 & -0.6884 & -0.14 & 10.3976 & 1.11 \\
\hline Germany & 0.1259 & 0.39 & 2.3024 & 0.37 & 12.1291 & 1.08 \\
\hline France & 0.4368 & 1.88 & 8.4485 & 1.96 & 13.0224 & 1.48 \\
\hline Israel & 0.1980 & 0.84 & 7.3303 & 1.83 & 34.3074 & 4.39 \\
\hline Japan & -1.0868 & -3.13 & 9.4064 & 1.76 & 21.4069 & 1.82 \\
\hline $\begin{array}{l}\text { Time listed in } \\
\text { U.S. }\end{array}$ & 0.0000 & 1.36 & -0.0007 & -1.29 & -0.0030 & -2.07 \\
\hline $\begin{array}{l}\text { Board ties to } \\
\text { U.S. companies }\end{array}$ & 0.0857 & 2.95 & 0.8414 & 1.51 & -0.7903 & -0.48 \\
\hline Computers & 0.5903 & 1.44 & 11.7725 & 1.64 & -18.4736 & -1.21 \\
\hline $\begin{array}{l}\text { Communications } \\
\text { equipment }\end{array}$ & 0.9078 & 2.75 & -0.0807 & -0.01 & -7.7560 & -0.66 \\
\hline $\begin{array}{l}\text { Electronic } \\
\text { components }\end{array}$ & 0.5350 & 1.33 & -3.9108 & -0.52 & 19.1267 & 1.47 \\
\hline $\begin{array}{l}\text { Software/info } \\
\text { processing }\end{array}$ & 0.1040 & 0.43 & -6.9773 & -1.69 & 7.4063 & 0.95 \\
\hline Biotech & -19.0807 & 0.00 & -4.2250 & -0.33 & & \\
\hline Constant & 0.3946 & 1.77 & 12.4934 & 3.14 & -15.9941 & -1.83 \\
\hline & $\mathrm{n}=193, \chi$ & $2=74.1$ & $\mathrm{n}=185, \mathrm{l}$ & $2^{2}=.18$ & $\mathrm{n}=193, \chi$ & $2=46.1$ \\
\hline
\end{tabular}

Germany, Israel, Japan, and the UK varied widely. Most Chilean and Japanese firms were isolates; older French firms were densely connected among themselves but not to firms from other nations, while new economy French firms had varied ties; and Israeli firms were well-connected among themselves and to high-tech U.S. firms, typically through venture capitalists on their boards. German and British firms often inherited American directors in the wake of their acquisitions. Overall, the patterns of governance among U.S.-listed firms mirrored the patterns of their domestic counterparts.

We were particularly interested in whether sharing directors with U.S. corporations acted to spread norms of corporate governance among non-U.S 
firms. As it happens, most foreign corporations do not avail themselves of this channel. Firms with a large market capitalization were more likely to share directors with U.S. firms, but national origin had a larger impact on U.S. interlocks. No Chilean firms shared directors with a U.S. firm and very few Japanese firms did so, while most British firms interlocked with at least one American firm, and U.S. ties were quite common among Israeli firms. These ties were also associated with patterns of disclosure and with the size of analyst following. Because our data are contemporaneous, we cannot demonstrate that the U.S. ties led the disclosure practices and analyst interest; it is also possible that disclosure and board composition are jointly decided upon, and that the size of analyst following is a result. But prior research finds that interlock ties play an important role in reinforcing normative standards among directors (e.g., Davis and Greve 1997), and U.S. ties in particular are valued by the stock market (Randey and Oxelheim 2001). Time will tell if these ties have an ongoing impact on firm governance.

We find no support for the notion that firms move in the direction of U.S. practice simply as a result of their time listed on a U.S. market- the long-tenured firms had large boards and had less accessible disclosures, which are the opposite of what we would have expected. (The negative relation between time listed and size of the largest ownership block is most likely due to failures of disclosure, not a positive impact of U.S. listing on governance.) Indeed, it is the most recently listed firms-particularly those from Israel - that appeared closest to the U.S. standard.

We considered several possible trajectories for U.S.-listed firms with respect to their governance practices. We can reject two of them: foreign firms do not adopt U.S. governance practices prior to listing in the U.S., nor do they gravitate in that direction with time. There is a modest association between appointing U.S. directors and making more (and more accessible) disclosures, and these firms attract more analysts. But most foreign firms do not appoint U.S. directors, adopt U.S. governance practices, or receive much investor recognition. Indeed, institutional investors owned just 0.3 percent of the median Chilean firm, compared to 49 percent for all NYSE-listed firms. It appears that core aspects of governance, such as the size and structure of the board of directors, are not malleable and maintain their distinctive national structure even after a U.S. listing, whereas a firm's investor interface-how it portrays itself to the investor world, and how many analysts it attracts-are influenced by ties to U.S. companies. U.S.-listed firms may wear American fashions, but they continue to speak in their native tongue.

The major exception to these generalizations is Israeli firms. As we remarked previously, these firms are often funded by American venture capitalists who then serve on their boards, and their exit strategy is to go 
public in the U.S., typically bypassing their domestic stock exchange. Many Israeli firms have headquarters or representative offices in the U.S., and some are incorporated in an American state (see Rock 2000 for details). These new economy firms are largely indistinguishable in their corporate governance practices from U.S. firms in the same industries (mostly software and electronics); indeed, they were created in their image. In contrast, Chilean firms are primarily in financial services, utilities, and beverages, and the median firm was roughly eighty years old.

This suggests an interpretation of our findings that accords with Stinchcombe's "organizational archeology": because the governance structures of firms reflect the balance of power in society, they are likely to be highly institutionalized and resistant to substantial change. Firms founded in earlier eras will have governance structures that reflect the priorities of their time and place, and a U.S. listing will have minimal impact. But new firms, particularly those founded under the influence of "shareholder capitalism" (such as start-ups in Israel), will be structured to reflect the expectations about good governance embedded in financial markets. Put another way, the engine of convergence in corporate governance is likely to be the creation of new firms, not the transformation of old ones (much less societallevel transformation). Core elements of corporate governance, such as the size and structure of the board, are unaffected by ties to U.S. firms; in contrast.

\section{Conclusion}

We have argued that the contemporary debate about convergence in corporate governance is most usefully framed at the level of the firm and its decision-makers. Over the past decade, public corporations around the world have faced a range of choices of institutional jurisdiction; in particular, for many firms the place of incorporation and the market on which securities are traded are no longer dictated by geography. Changes on the demand side for corporate and securities laws most likely will not lead to convergence in legal regimes, but there is a plausible case to be made for firm-level convergence in governance structures. By hypothesis, public corporations gravitate toward the institutions that are perceived to be best for investors, creating a "race to the top" among institutional regimes in a process that ultimately favors U.S. securities markets (Easterbrook and Fischel 1991; Romano 1993; Coffee 1999). Also by hypothesis, public firms will voluntarily adopt the structures that best reflect the interests of investors.

We have explored the argument that foreign firms listing on U.S. stock markets may come to adopt the American shareholder capitalist approach to 
their discretionary corporate governance practices. Such firms are subject to U.S. securities regulations, and are required to file financial statements and other disclosures consistent with relatively stringent requirements (GAAP or similar). On average, they are rewarded with higher stock market valuations, and thus U.S. markets could be part of a race to the top in corporate governance practices, as global corporations converge in their practices in order to gain the benefits of a U.S. listing. But while there are a handful of highly visible examples of this-and the story appears broadly applicable to Israeli firms listed in the U.S. - we found little evidence for it as a general account. On average, the foreign firms we studied organize their boards in the same ways as their domestic counterparts. Few make their financial statements available electronically to (potential) investors. They typically attract few equity analysts and receive very little interest from institutional investors (a median of under 2 percent). And the lack of transparency of their ownership structures suggests that the SEC's enforcement does not extend beyond U.S. borders. In short, while "the United States boasts a . . vast industry of securities houses and securities analysts [and] the American market operates as a powerful monitoring and pricing system" (Licht 1998:582), foreign issuers are not especially well integrated into this system as of yet. At this time, the choice to list on a U.S. securities market may be intended as a signal of shareholder-friendly governance, but it is evidently not followed by other substantial structural changes.

There are, of course, exceptions. Firms that recruit American directors also have more accessible disclosure and attract more analysts. Even one tie to an American firm is sufficient to place a firm within "six degrees of separation" from JP Morgan Chase-the best-connected board in corporate America (Davis et al. 2003). And some foreign firms-particularly those that retained directors after acquiring a major U.S. corporation-are well acquainted with the American corporate governance genre. Moreover, the required disclosures that accompany a U.S. listing are not trivial and may in themselves induce changes in some aspects of corporate governance over time (cf. Fox 1998). But our findings suggest that issuer choice will not extend to core questions about the governance structure of the firm. New firms founded with the explicit intention of listing on U.S. markets will easily adapt to the standards of American investors, but old and large firms are unlikely to do so because their governance is more "institutionalized" (in Stinchcombe's 1965 sense). Based on the evidence currently available, the vision of the dominant multinationals around the world converging on American practice appears remote.

We see two theoretical implications of our findings for the economic sociology of capitalism. First, recent discussions of law, culture, and financial markets have taken a turn toward highly stylized depictions of relatively frictionless institutional change. With the right nudge from the IMF or other 
international advisors, nations might install American-style shareholder capitalism, with a realignment of other national institutions to follow. Yet if foreign firms that voluntarily list on the New York Stock Exchange continue to be imprinted by their home institutions, we have little reason to expect that those institutions themselves will easily shift directions. As James Scott pointed out in Seeing like a State (1998), there is often a substantial gulf between the simple institutional blueprints of policymakers and how institutional change happens on the ground. Second, our approach has been to take the corporation as the relevant unit of analysis and to consider alternative mechanisms by which institutional change-in this case, convergence in corporate governance-is accomplished. Firms might converge in their practices via contagion through social networks linking their decisionmakers, or through voluntary adoption of the practices of exemplars, or through differential failure rates of firms with and without those practices, or through simple drift over time. In our case, we found that it was new entrants most prone toward convergence on the American model, while incumbents generally maintained their traditional governance practices over time. But it was organizational processes that were the cogs and wheels underlying (dis)continuity in institutional structures. This is the distinctive contribution that organization theory can make to the economic sociology of capitalist institutions.

\section{Note}

1. By "listed" we include firms that trade only on a U.S. market and those that trade on both a local market and a U.S. market, typically by sponsoring American Depository Receipts (ADRs).

\section{REFERENCES}

Berle, Adolph, Jr. and Gardiner C. Means. 1932. The Modern Corporation and Private Property. New York: Macmillan.

Blair, Margaret M. 1995. Ownership and Control: Re-Thinking Corporate Governance for the Twenty-First Century. Washington, D.C.: Brookings Institution Press.

Bradley, Michael, Cindy Schipani, Anant K. Sundaram, and James P. Walsh. 1999. "The Purposes and Accountability of the Corporation in Contemporary Society: Corporate Governance at a Crossroads." Law and Contemporary Problems 62(3): 9-85.

Charkham, Jonathan. 1994. Keeping Good Company: A Study of Corporate Governance in Five Countries. Oxford: Oxford University Press. 
Coffee, John C., Jr. 1999. "The Future as History: The Prospects for Global Convergence in Corporate Governance and Its Implications." Northwestern University Law Review 93: 641-720.

Conference Board. 1999. Globalizing the Board of Directors: Trends and Strategies. New York: Conference Board.

Coopers \& Lybrand. 2000. The Coopers \& Lybrand SEC Manual. 7th ed. New York: Wiley.

Davis, Gerald F. and Henrich R. Greve. 1997. "Corporate Elite Networks and Governance Changes in the 1980s." American Journal of Sociology 103: $1-37$.

Davis, Gerald F., Mina Yoo, and Wayne Baker. 2003. "The Small World of the American Corporate Elite, 1982-2001." Strategic Organization 1: 301-26.

Deutsche Presse-Agentur. 1997. "Krupp-Hoesch Takeover of Thyssen Already Mapped Out." March 22.

DiMaggio, Paul and Walter W. Powell. 1983. "The Iron Cage Revisited: Institutional Isomorphism and Collective Rationality in Organizational Fields." American Sociological Review 48: 147-60.

Easterbrook, Frank H. and Daniel R. Fischel. 1991. The Economic Structure of Corporate Law. Cambridge, Mass.: Harvard University Press.

Economist. 2001. "A Long Arm for Securities Law: Foreign Listings in America." May 19, 65.

Fennema, Meindert and Huibert Schijf. 1985. "The Transnational Network." In Networks of Corporate Power: A Comparative Analysis of Ten Countries, ed. Frans N. Stokman, Rolf Ziegler, and John Scott. Oxford: Polity Press.

Fox, Merritt B. 1998. "Required Disclosure and Corporate Governance." In Comparative Corporate Governance: The State of the Art and Emerging Research, ed. Klaus J. Hopf, Hideki Kanda, Mark J. Roe, Eddy Wymeersch, and Stefan Prigge. Oxford: Oxford University Press.

Friedman, Thomas L. 1999. The Lexus and the Olive Tree: Understanding Globalization. New York: Farrar, Straus, Giroux.

Geiger, Uri. 1998. "Harmonization of Securities Disclosure Rules in the Global Market: A Proposal.” Fordham Law Review 66: 1785-1836.

Gilson, Ronald J. 2000. "Globalizing Corporate Governance: Convergence of Form or Function." Columbia Law School.

Granovetter, Mark S. 1994. "Business Groups." In The Handbook of Economic Sociology, ed. Neil J. Smelser and Richard Swedberg. Princeton: Princeton University Press.

Guillen, Mauro F. 2001. "Corporate Governance and Globalization: Is There Convergence across Countries?" Advances in International Comparative Management 13: 175-204.

Haunschild, Pamela. 1993. "Interorganizational Imitation: The Impact of Interlocks on Corporate Acquisition Activity." Administrative Law Quarterly 38: 546-92.

Hedstrom, Peter and Richard Swedberg, eds. 1998. Social Mechanisms: An Analytical Approach to Social Theory. Cambridge: Cambridge University Press.

Hopt, Klaus J. 1998. "The German Two-Tier Board: Experience, Theories, Reforms." In Comparative Corporate Governance: The State of the Art and Emerging 
Research, ed. Klaus J. Hopt, Hideki Kanda, Mark J. Roe, Eddy Wymeersch, and Stefan Prigge. Oxford: Oxford University Press.

Kadushin, Charles. 1995. "Friendship among the French Financial Elite." American Sociological Review 60: 202-21.

Kanda, Hideki. 1998. "Comparative Corporate Governance-Country Report: Japan." In Comparative Corporate Governance: The State of the Art and Emerging Research, ed. Klaus J. Hopt, Hideki Kanda, Mark J. Roe, Eddy Wymeersch, and Stefan Prigge. Oxford: Oxford University Press.

Khanna, Tarun and Krishna Palepu. 2000. "The Future of Business Groups in Emerging Markets: Long-Run Evidence from Chile." Academy of Management Journal 43: 268-85.

LaPorta, Rafael, Florencio López-de-Silanes, Andrei Shleifer, and Robert Vishny. 1999. "The Quality of Government." Journal of Law, Economics, and Organization 14: 222-82.

Levine, Ross and Sara Zervos. 1998. "Stock Markets, Banks, and Economic Growth." American Economic Review 88: 537-54.

Licht, Amir N. 1998. "Regulatory Arbitrage for Real: International Securities Regulation in a World of Interacting Securities Markets." Virginia Journal of International Law 38: 563-638.

2000. "Stock Exchange Mobility, Unilateral Regulation, and the Privatization of Securities Regulation." Interdisciplinary Center Jerzliya, Israel.

. 2001. "Stock Exchange Mobility, Unilateral Regulation, and the Privatization of Securities Regulation." Virginia Journal of International Law 41(3): 583-628.

Modigliani, Franco and Enrico C. Perotti. 1998. "Security versus Bank Finance: The Importance of a Proper Enforcement of Legal Rules." MIT Sloan School of Management.

Morck, Randall K., David A. Stangeland, and Bernard Young. 1998. "Inherited Wealth, Corporate Control, and Economic Growth: The Canadian Disease." NBER Working Paper 6814. National Bureau of Economic Research online.

North, Douglass C. 1990. Institutions, Institutional Change and Economic Performance. Cambridge: Cambridge University Press.

Prigge, Stefan. 1998. "A Survey of German Corporate Governance." In Comparative Corporate Governance: The State of the Art and Emerging Research, ed. Klaus J. Hopt, Hideki Kanda, Mark J. Roe, Eddy Wymeersch, and Stefan Prigge. Oxford: Oxford University Press.

Rajan, Raghuram G. and Luigi Zingales. 2001. "The Great Reversals: The Politics of Financial Development in the 20th Century." CRSP Working Paper 6. University of Chicago Graduate School.

Randøy, Trond and Lars Oxelheim. 2001. "The Impact of Foreign Board Membership on Firm Value." IUI Working Paper 567, Agder University College, Norway.

Rao, Hayagreeva, Gerald F. Davis, and Andrew Ward. 2000. "Embeddedness, Social Identity, and Mobility: Why Firms Leave the NASDAQ and Join the New York Stock Exchange." Administrative Science Quarterly 45: 268-92.

Rao, Hayagreeva, Henrich R. Greve, and Gerald F. Davis. 2001. "Fool's Gold: Social Proof in the Initiation and Discontinuation of Coverage by Wall Street Analysts." Administrative Science Quarterly 46: 502-26. 
Rao, Hayagreeva and Kumar Sivakumar. 1999. "Institutional Sources of BoundarySpanning Structures: The Establishment of Investor Relations Departments in the Fortune 500 Industrials." Organization Science 10: 27-42.

Reese, William A., Jr. and Michael Weisbach. 2000. "Protection of Minority Shareholder Interests, Cross-Listings in the United States, and Subsequent Equity Offerings." Paper presented at Sixth Annual Meeting of the Latin American Research Consortium, Tulane University, March.

Rock, Edward B. 2001. "Greenhorns, Yankees, and Cosmopolitans: Venture Capital, IPOs, Foreign Firms, and U.S. Markets.” Theoretical Inquiries in Law 2: 711.

Roe, Mark J. 1994. Strong Managers, Weak Owners: The Political Roots of American Corporate Finance. Princeton: Princeton University Press.

Romano, Roberta. 1993. The Genius of American Corporate Law. Washington, D.C.: American Enterprise Institute.

Scott, James C. 1998. Seeing like a State: How Certain Schemes to Improve the Human Condition Have Failed. New Haven: Yale University Press.

Scott, W. Richard. 1995. Institutions and Organizations. Thousand Oaks, Calif.: Sage.

Shleifer, Andrei and Robert W. Vishny. 1997. "A Survey of Corporate Governance." Journal of Finance 52: 737-83.

Stinchcombe, Arthur I. 1965. "Social Structure and Organization." In Handbook of Organizations, ed. James G. March. Chicago: Rand McNally.

Stokman, Frans N., Rolf Ziegler, and John Scott, eds. 1985. Networks of Corporate Power: A Comparative Analysis of Ten Countries. Oxford: Polity Press.

Useem, Michael. 1996. Investor Capitalism: How Money Managers Are Changing the Face of Corporate America. New York: Basic Books.

. 1998. "Corporate Leadership in a Globalizing Equity Market." Academy of Management Executive 12: 43-59.

Velli, Joseph. 1994. "American Depository Receipts: An Overview." Fordham International Law Journal 17: 38-50.

Murray, Alan. 1997. "Super Model: Asia' financial Foibles Make American Way Look like a Winner." Wall Street Journal, December 8, Al.

Weber, Klaus and Gerald F. Davis. 2000. "The Global Spread of Stock Exchanges, 1980-1998." William Davidson Institute Working Paper 341, University of Michigan Business School.

World Bank. 1997. Private Capital Flows to Developing Countries: The Road to Financial Integration. Oxford: Oxford University Press.

Wymeersch, Eddy. 1998. "A Status Report on Corporate Governance in Some Continental European States." In Comparative Corporate Governance: The State of the Art and Emerging Research, ed. Klaus J. Hopt, Hideki Kanda, Mark J. Roe, Eddy Wymeersch, and Stefan Prigge. Oxford: Oxford University Press. 